\title{
Production, Partial Purification and Characterization of Lipase Enzyme Expressed by Klebsiella pnemoniae of Vegetable Oil Contaminated Soil
}

\author{
Moses Bali Emmanuel ${ }^{1,2, *}$, Egwim Chidi Evans², Abdulkadir Abubakar², Liman Mubarak Labaran³, \\ Alex Victoria Ali ${ }^{1}$, Manya Zabe ${ }^{1}$ \\ ${ }^{1}$ Department of General Studies, School of Agricultural Technology, Nuhu Bamalli Polytechnic, Nigeria \\ ${ }^{2}$ Department of Biochemistry, School of Life Sciences, Federal University of Technology, Nigeria \\ ${ }^{3}$ Department of Science Laboratory Technology, School of Applied Sciences, Nuhu Bamalli Polytechnic, Nigeria
}

Received May 14, 2020; Revised August 13, 2020; Accepted August 25, 2020

\section{Cite This Paper in the following Citation Styles}

(a): [1] Moses Bali Emmanuel, Egwim Chidi Evans, Abdulkadir Abubaka, Liman Mubarak Labaran, Alex Victoria Ali, Manya Zabe , "Production, Partial Purification and Characterization of Lipase Enzyme Expressed by Klebsiella pnemoniae of Vegetable Oil Contaminated Soil," International Journal of Biochemistry and Biophysics, Vol. 8, No. 2, pp. 30 - 39, 2020. DOI: 10.13189/ijbb.2020.080202.

(b): Moses Bali Emmanuel, Egwim Chidi Evans, Abdulkadir Abubaka, Liman Mubarak Labaran, Alex Victoria Ali, Manya Zabe (2020). Production, Partial Purification and Characterization of Lipase Enzyme Expressed by Klebsiella pnemoniae of Vegetable Oil Contaminated Soil. International Journal of Biochemistry and Biophysics, 8(2), 30 - 39. DOI: 10.13189/ijbb.2020.080202.

Copyright $\bigcirc 2020$ by authors, all rights reserved. Authors agree that this article remains permanently open access under the terms of the Creative Commons Attribution License 4.0 International License

\begin{abstract}
Lipases are a versatile class of enzymes owing to their ability to perform a specific range of biotransformations. Bacteria for lipase production were cultured on nutrient agar (NA) plates and identified using Gram Stain and biochemical tests. Screening for lipase producers was performed on NA media supplemented with $3 \%$ olive oil at $37{ }^{\circ} \mathrm{C}$. Seven bacteria were isolated and identified as Bacillus megaterium, Klebsiella pneumoniae, Escherichia coli, Bacillus subtilis, Bacillus licheniformis and Micrococcus luteus. Lipase production was carried using standard methods and the best lipase producer was purified and characterized. The lipase enzyme from $K$. pneumoniae had a yield of $18.8 \%$ and was purified 26.3 fold. The optimum $\mathrm{pH}$ for the partially purified lipase was determined to be 8 with maximum activity at $30{ }^{\circ} \mathrm{C}$. The lipase enzyme had affinity for substrates in the following order, olive oil $>$ groundnut oil $>$ palm oil and the activity of the enzyme was enhanced by metal ions in the following order, $\mathrm{MgCl}_{2}>\mathrm{CaCl}_{2}>\mathrm{KCl}$ whereas inhibitory effects were observed in the following order, $\mathrm{CoCl}_{2}>\mathrm{HgCl}_{2}>$ $\mathrm{CuSO}_{4}>\mathrm{FeCl}_{3}$. The lipase enzyme had $\mathrm{V}_{\max }$ of 0.0006 $\mathrm{U} / \mathrm{Sec}, \mathrm{K}_{\mathrm{m}}$ of $0.4960 \mathrm{mM}$ and $\mathrm{K}_{\mathrm{cat}}$ of $0.0125 \mathrm{~S}^{-1}$.
\end{abstract}

Keywords Klebsiella pneumoniae, Lipase,
Production, Purification, Biochemical Properties

\section{Introduction}

Lipases, classified as triacylglycerol acylhydrolase (EC 3.1. 1.3) belong to the family of hydrolases which act on carboxylic ester bonds. Their physiological role is to hydrolyze triglycerides to diglycerides monoglycerides, fatty acids and glycerol [1]. They constitute one of the most important group of biocatalyst for biotechnological applications [2]. Lipase-catalyzed processes generally offer cost-effectiveness as against the traditional downstream processing having the problems of energy consumption and toxic by-products [1].

Microbial enzymes are considered more useful than enzymes of plant and animal derivatives due to their stability, selectivity, and broad substrate specificity $[3,4]$, versatility of molecular structure, the great variety of catalytic activities they possess, the high yields possible, ease of genetic manipulation, regular supply due to absence of seasonal fluctuations, rapid growth of microorganisms 
on an inexpensive media and low waste production [5]. They are also safer and have the possibility of use in continuous operation, ease of recovery and reuse, cost benefit and low required downstream processing [6]. Also, lipolytic enzymes secreted into culture medium by the various fungi and bacteria have attracted substantial attention as a result of their biotechnological potentials [7].

Microbial lipases are regarded as biotechnological machineries and this has increased the search for novel lipases and variants from natural sources [8]. Bacterial lipases are present in the strains of Pseudomonas aeruginosa, Serratia marescens [9] and Bacillus species [10]. Other genera of lipase producers which have been studied include; Acinetobacter [11], Staphylococcus, Streptococcus, Burkholderia, Achromobacter, Arthrobacter, Alcaligenes, Chromobacterium and Streptomyces [12,13].

Exploration of biodiversity is the emerging trend in present day biotechnology [14] yet not so much has been done in exploring microbial lipases from $K$. pneumoniae. The present study therefore sought to isolate lipase producing organisms from vegetable oil contaminated soils, partially purify and characterize the best lipase producer.

\section{Materials and Methods}

\subsection{Sample Collection}

Soil samples were collected from vegetable oil contaminated soil of Falke Factory, Kaduna State and Grand Cereal Factory, Plateau State. Five random spots of about $1 \mathrm{~m}$ apart to a depth of $4-6 \mathrm{~cm}$ were fetched with the help of a sterile spatula, bulked together and placed in sterile plastic bags. All the soil samples from Falke Factory, Kaduna were labelled as $\mathrm{F}$ while samples from Grand Cereal Factory, Plateau State were labelled as G. The soil samples were placed immediately in an ice packed flask and brought to the laboratory within $24 \mathrm{hr}$. The samples were sealed in sterile containers and stored in the refrigerator at $4{ }^{\circ} \mathrm{C}$ until screening.

\subsection{Isolation and Identification of Lipolytic Bacterial Species}

Isolation of lipolytic microorganisms was carried out according to the method described by [15] with slight modification. Soil samples were serially diluted up to $10^{6}$ times in sterile distilled water, after which $1 \mathrm{ml}$ inoculums of $10^{6}$ dilutions were placed on nutrient agar (NA) by spread plate method to quantify the total microbial population. The bacterial inoculated plates were incubated at $37{ }^{\circ} \mathrm{C}$ for $24 \mathrm{hr}$ and colonies which appeared were immediately brought in subculture. The bacterial species were identified using grams stain and biochemical test as described by [16]. A pure culture of each isolate was maintained on NA slant at $4{ }^{\circ} \mathrm{C}$ until enzyme production.

\subsection{Lipolytic Efficiency of Bacterial Species from Different Oil Contaminated Soil}

All the strains were separately inoculated on NA media supplemented separately with $1 \%(\mathrm{v} / \mathrm{v})$ olive oil. The $\mathrm{pH}$ of the media in all cases were maintained at 7.2 and incubation carried out at $37^{\circ} \mathrm{C}$ for up to $48 \mathrm{hr}$. Any clear zone produced surrounding bacterial colony indicated production of extracellular lipase. The lipolytic efficiency (LE) of each isolate was calculated by using the following formula [17]:

$$
L E(\%)=\frac{Z-A}{Z} \times 100
$$

Where,

Z: Zone of hydrolysis including colony diameter

A: Diameter of colony growth.

\subsection{Lipase Production from Selected Isolates of Different Vegetable Oil Contaminated Soil}

Microbial isolates for lipase production were finally selected based on their lipolytic efficiency. The composition of the basal medium used in this study was as follows (g/L): $\mathrm{MgSO}_{4} .7 \mathrm{H}_{2} \mathrm{O}(0.1), \mathrm{KH}_{2} \mathrm{PO}_{4}(1.0), \mathrm{K}_{2} \mathrm{HPO}_{4}$ (3.0), $\mathrm{Na}_{2} \mathrm{SO}_{4}$ (2.0), yeast extract (5.0), peptone (5.0), glucose (2.0) and olive oil (3\% v/v). The initial $\mathrm{pH}$ of the medium was adjusted to $\mathrm{pH}$ 7.0. Lipase productions were carried out in $50 \mathrm{~mL}$ production media with initial inoculation of $0.5 \%(\mathrm{v} / \mathrm{v})$ inside $250 \mathrm{~mL}$ Erlenmeyer flasks under shaking speed of $150 \mathrm{rpm}$ at $37^{\circ} \mathrm{C}$ for successively 4 days. Total protein as well as lipase activity were assayed at $12 \mathrm{hr}$ interval.

\subsection{Enzyme Assay}

Lipolytic activity was determined according to the method of [18] with slight modification following the hydrolysis of Tween 80 at $25^{\circ} \mathrm{C}$ and measured spectrophotometrically at $450 \mathrm{~nm}$. $200 \mu \mathrm{L}$ of the enzyme was added to $800 \mu \mathrm{L}$ of the substrate solution containing $1 \%(\mathrm{v} / \mathrm{v})$ Tween 80 in $20 \mathrm{mM}$ Tris-HCl (pH 8.5) and 80 $\mathrm{mM} \mathrm{CaCl} 2$. The hydrolysis rate of Tween 80 was directly monitored by measuring the change in absorbance over 5 min. Lipase with the best lipolytic efficiency and least time of incubation was further selected for purification.

\subsection{Total Protein Determination}

This was determined by using the method of [19]. Briefly, to $5 \mathrm{~mL}$ of Bradford reagent, $1 \mathrm{~mL}$ of the sample was added after which the reaction mixture was allowed to stand for $5 \mathrm{~min}$ at room temperature and absorbance was read spectrophotometrically at $590 \mathrm{~nm}$. The amount of protein was determined by extrapolating from the egg 
albumin (EA) standard curve (it was constructed by using a solution containing $1 \mathrm{mg} / \mathrm{mL} \mathrm{EA})$.

\subsection{Enzyme Purification}

The lipase enzyme culture from Klebsiella pneumoniae was centrifuged at $4000 \mathrm{rpm}$ for $40 \mathrm{~min}$ at $10^{\circ} \mathrm{C}$ to remove cells after which ammonium sulphate was added to $30 \mathrm{~mL}$ of the culture supernatant which was stirred constantly in order to bring saturation to $40 \%$. The mixture was left overnight at $4{ }^{\circ} \mathrm{C}$ and the precipitate removed by centrifugation at $4000 \mathrm{rpm}$ for $1 \mathrm{hr}$. Five millilitre of the concentrated enzyme of ammonium sulphate fraction was loaded onto Sephadex G-75 column already equilibrated with $10 \mathrm{mM}$ phosphate buffer ( $\mathrm{pH}$ 7.0). The enzyme was eluted from the column at a flow rate of $0.5 \mathrm{~mL} / \mathrm{min}$ using phosphate buffer (pH 7.0). Enzyme fractions (3 mL each) were collected and protein content measured as described in 2.6 above while lipase assay was performed as in 2.5 above.

\subsection{Physicochemical and Biochemical Characterization of Purified Lipases from Klebsiella pneumoniae of Vegetable Oil Contaminated Soil}

\subsubsection{Effect of $\mathrm{pH}$}

To determine the optimum $\mathrm{pH}$ of the enzyme, $200 \mu \mathrm{L}$ of the enzyme was incubated with $1 \mathrm{M}$ Tris-HCl buffer at $\mathrm{pH}$ range 4 - 10 and assayed for lipase activity as in 2.5 above. A graph of lipase activity versus $\mathrm{pH}$ was plotted in order to determine the optimum $\mathrm{pH}$.

\subsubsection{Effect of Temperature}

To study the temperature response of the enzyme, Lipase assay was carried out as described in 2.5 above and incubated at different temperatures, from 10 to $80^{\circ} \mathrm{C}$ for 30 minutes. A graph of lipase activity versus temperature was plotted in order to determine the optimum temperature.

\subsubsection{Effect of Different Substrates on Lipase Activity}

The effect of different substrates was studied by substituting 1\% Tween 80 with different oils (1\%): olive oil, palm oil and groundnut oil and assayed as in 2.5 above.

\subsubsection{Effect of Different Metal Ions on Lipase Activity}

Lipase activity was also determined in the presence of metal ions by incubating $200 \mu \mathrm{L}$ of the enzyme separately in different test tubes with $0.2 \mu \mathrm{L}$ of $1 \mathrm{mM}$ solution of each salt, i.e., $\mathrm{FeCl}_{3}, \mathrm{CoCl}_{2}, \mathrm{HgCl}_{2}, \mathrm{MgCl}_{2}, \mathrm{CuSO}_{4}, \mathrm{CaCl}_{2}$ and $\mathrm{KCl}$ at $25^{\circ} \mathrm{C}$ for $1 \mathrm{hr}$ and assayed for lipase activity as in 2.5 above. Comparative lipase activities were determined for each metal ion from the activity of the control sample which had no metal ion.

\subsubsection{Determination of Kinetic Parameters $\left(\mathrm{K}_{\mathrm{m}}\right.$ and $\left.\mathrm{V}_{\max }\right)$}

The substrate concentration was varied over the range of $0.02-1.80 \mathrm{v} / \mathrm{v}$ of Tween 80 . The activity of lipase for each was carried out in the standard enzyme assay in 2.5 above. The kinetic constants $K_{m}$ and $V_{\max }$ for lipase were determined from the Lineweaver - Burk (double reciprocal) plot and $\mathrm{k}_{\mathrm{cat}}$ was calculated as well. The energy of activation (Ea) and half-life ( $\left.t_{1 / 2}\right)$ of the purified enzyme were also determined by using the Arrhenius plot.

\subsection{Statistical Analysis}

Experiments were performed in triplicates and the means of results determined were calculated using Statistical Package for Social Science (SPSS) version 23.

\section{Results and Discussion}

In this study, Bacillus megaterium, Escherichia coli, Bacillus subtilis, micrococcus luteus, Bacillus licheniformis and Klebsiella pneumoniae were the bacterial species present in the different oil contaminated soil (Table 1). This however, shows the biodiversity of the different oil contaminated soil. Sharada and Ramakrishna [5] have reported microbial biodiversity from oil contaminated soil. The bacterial species isolated may be potential lipase producers with novel and specific properties along with lower processing and production cost. 
Table 1. Lipolytic bacterial species isolated from different vegetable oil contaminated soil

\begin{tabular}{|c|c|c|c|c|c|c|c|c|c|c|c|c|c|c|c|}
\hline \multirow{2}{*}{$\begin{array}{l}\text { Bacteria } \\
\text { Isolate }\end{array}$} & \multirow{2}{*}{$\begin{array}{l}\text { Gram } \\
\text { Stain }\end{array}$} & \multirow{2}{*}{$\begin{array}{c}\text { Catalase } \\
\text { Test }\end{array}$} & \multirow{2}{*}{$\begin{array}{c}\text { Coagulaase } \\
\text { Test }\end{array}$} & \multirow{2}{*}{$\begin{array}{c}\text { Starch } \\
\text { Hydrolysis } \\
\text { Test } \\
\end{array}$} & \multirow{2}{*}{$\begin{array}{c}\mathrm{H}_{2} \mathrm{~S} \\
\text { Production } \\
\text { Test } \\
\end{array}$} & \multirow{2}{*}{$\begin{array}{c}\text { Citrate } \\
\text { Utilization } \\
\text { Test } \\
\end{array}$} & \multirow{2}{*}{$\begin{array}{c}\text { Indole } \\
\text { Production } \\
\text { Test } \\
\end{array}$} & \multirow{2}{*}{$\begin{array}{c}\text { Methyl } \\
\text { Red } \\
\text { Test } \\
\end{array}$} & \multirow{2}{*}{$\begin{array}{c}\text { Voges } \\
\text { Proskauer } \\
\text { Test } \\
\end{array}$} & \multirow{2}{*}{$\begin{array}{c}\text { Urease } \\
\text { Production } \\
\text { Test } \\
\end{array}$} & \multirow{2}{*}{$\begin{array}{c}\text { Blood } \\
\text { Haemolysis } \\
\text { Test } \\
\end{array}$} & \multirow{2}{*}{$\begin{array}{c}\text { Oxidase } \\
\text { Production } \\
\text { Test } \\
\end{array}$} & \multicolumn{3}{|c|}{ Carbohydrate Utilization Tests } \\
\hline & & & & & & & & & & & & & Lactose & Sucrose & Glucose \\
\hline $\begin{array}{c}\text { Bacillus } \\
\text { megaterium }\end{array}$ & $+\mathrm{R}$ & + & - & + & - & - & - & - & - & - & - & - & - & + & + \\
\hline $\begin{array}{c}\text { Escherichia } \\
\text { coli }\end{array}$ & $-\mathrm{R}$ & - & - & - & - & + & + & + & - & - & - & - & + & + & + \\
\hline $\begin{array}{l}\text { Bacillus } \\
\text { subtilis }\end{array}$ & $+\mathrm{R}$ & + & - & + & - & + & - & - & + & - & $\alpha$ & - & - & + & + \\
\hline $\begin{array}{l}\text { Micrococcus } \\
\text { luteus }\end{array}$ & $+\mathrm{C}$ & + & - & - & - & - & - & - & - & - & - & - & - & - & + \\
\hline $\begin{array}{c}\text { Bacillus } \\
\text { licheniformis }\end{array}$ & $+\mathrm{R}$ & + & - & + & - & - & - & - & - & - & - & - & - & + & + \\
\hline $\begin{array}{c}\text { Klebsiella } \\
\text { pneumoniae }\end{array}$ & $-\mathrm{R}$ & + & - & - & + & + & - & + & - & + & - & - & + & + & + \\
\hline
\end{tabular}

Key: $\quad+\mathrm{R}=$ Gram positive bacteria $\quad-\mathrm{R}=$ Gram negative bacteria

$+\mathrm{C}=$ Gram positive cocci cells $\quad+=$ Positive (has reaction)

- = Negative (no reaction) $\quad \alpha=$ Alpha blood haemolysis 
Table 2. Lipolytic efficiency (LE) of bacterial species from different vegetable oil contaminated soil

\begin{tabular}{|c|c|c|c|}
\hline S/No & Bacterial Isolate & Source & LE (\%) \\
\hline 1 & Bacillus megaterium & G & $67.2 \pm 0.64$ \\
\hline 2 & Bacillus megaterium & F & $25 \pm 0.29$ \\
\hline 3 & Bacillus subtilis & F & $21.8 \pm 0.12$ \\
\hline 4 & Micrococcus luteus & G & $18.9 \pm 0.29$ \\
\hline 5 & Bacillus lichenifomis & F & $23.8 \pm 0.98$ \\
\hline 6 & Kblesiella pneumoniae & F & $91.7 \pm 5.02$ \\
\hline 7 & Eschericia coli & F & 0 \\
\hline
\end{tabular}

Reference to Table 2, out of the six (6) bacteria species identified as lipase producers, K. pneumoniae from Falke Vegetable Oil Factory, Kaduna had the highest lipolytic efficiency (91.7 \%) followed by Bacillus megaterium from Grand Cereals Vegetable Oil Factory, Plateau State (G) with lipolytic efficiency of $67.2 \%$. Bacillus megaterium from Falke Vegetable Oil Factory, Kaduna (F) had lipolytic efficiency of $25 \%$, Bacillus licheniformis from Falke Vegetable Oil Factory, Kaduna (F), 23.8 \%, Bacillus subtilis from Falke Vegetable Oil Factory, Kaduna (F), $21.8 \%$ and Micrococcus luteus having lipolytic efficiency of $18.9 \%$ from Grand Cereals Vegetable Oil Factory, Plateau State (G). Escherichia coli from Falke Vegetable Oil Factory, Kaduna (F) showed no zone of hydrolysis. This shows that the above organisms (with the exception of
E. coli) from the different oil contaminated soil have the ability to produce extracellular lipases in different quantities hence their purification and characterization for large scale production. Ghori [20] and Ramesh [21] reported lipase production from Bacillus $s p$. When considering source(s) of quantitative lipase production for different industrial and biotechnological applications, $K$. pneumoniae from Falke Vegetable Oil Factory, Kaduna (F) and Bacillus megaterium from Grand Cereals Vegetable Oil Factory, Plateau State (G) may be considered because of their ability to produce lipases in higher amounts.

Many studies have been carried out in order to determine the optimal culture and nutritional requirements for lipase production by submerged culture. Lipid as a carbon source is no doubt generally essential for obtaining a high lipase yield [22]. In the present study, olive oil was used as the substrate for lipase production. A number of other studies [22,21] verified olive oil as a sole specific substrate for enhanced lipase production when compared with other oil-inducers. $K$. pneumoniae was used for quantitative lipase production in liquid medium based on its earlier lypolytic efficiency. In the present study, lipase production from $K$. pneumoniae was observed to commence after $12 \mathrm{hr}$ of incubation and the activity declined with increase in time of incubation. However, lipase production was observed to be highest at $36 \mathrm{hr}$ as depicted in Figure 1. For this reason, the lipase from the present study may be employed for different industrial applications.

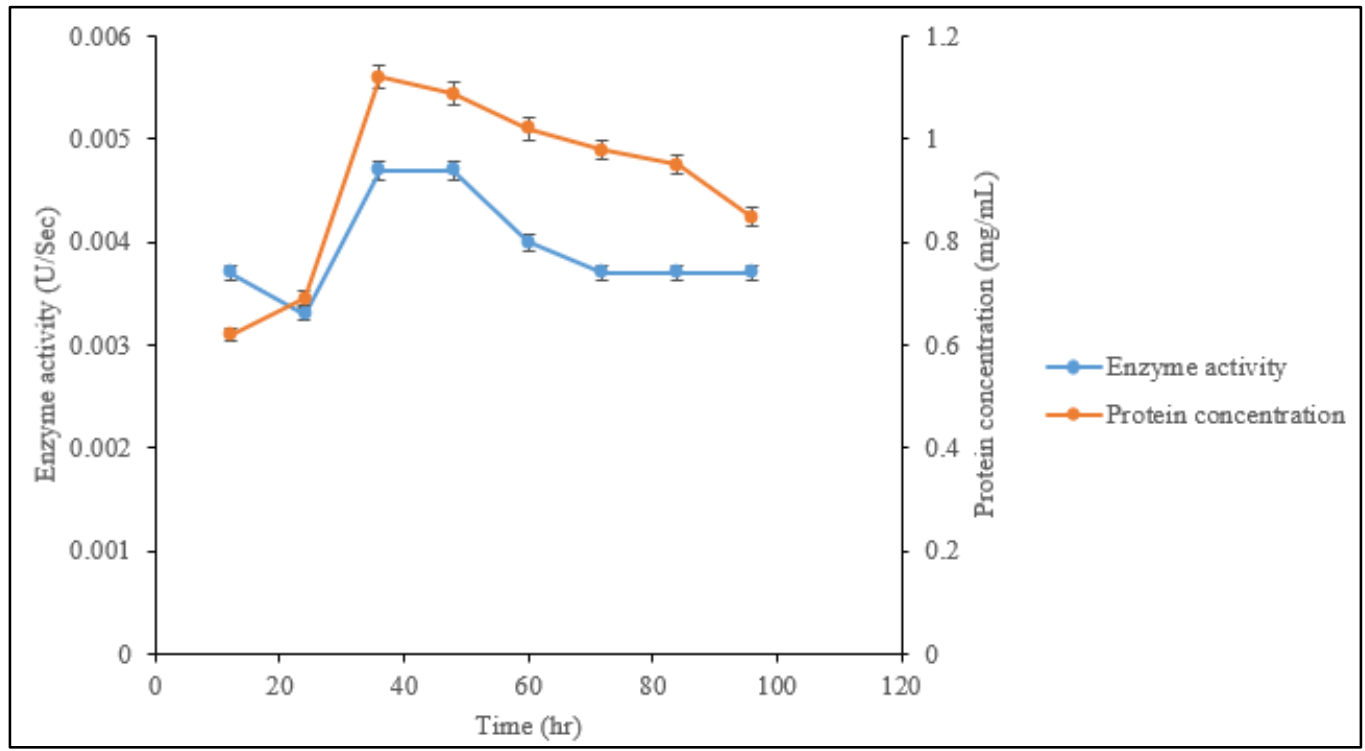

Figure 1. Time course for lipase production from Klebsiella pneumoniae isolated from a vegetable oil contaminated soil 


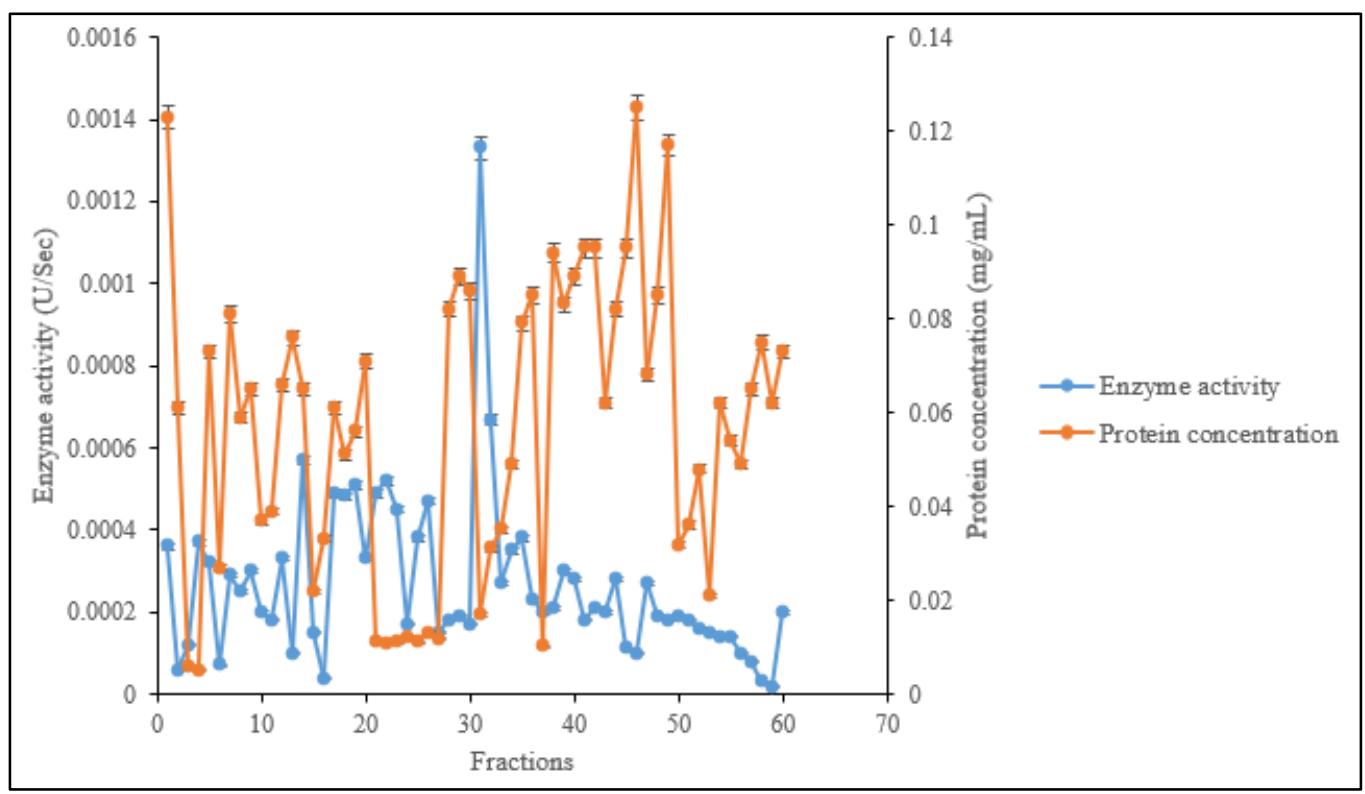

Figure 2. Elution profile of lipase from Klebsiella pneumoniae isolated from a vegetable oil contaminated soil

Table 3. Purification Table for Lipase from Klebsiella pneumoniae of a vegetable oil contaminated soil

\begin{tabular}{ccccccccc}
\hline Fraction & $\begin{array}{c}\text { Fraction } \\
\text { volume } \\
(\mathrm{mL})\end{array}$ & $\begin{array}{c}\text { Enzyme } \\
\text { activity } \\
(\mathrm{U} / \mathrm{Sec})\end{array}$ & $\begin{array}{c}\text { Total } \\
\text { activity } \\
(\mathrm{Units})\end{array}$ & $\begin{array}{c}\text { Protein } \\
\text { concentration } \\
(\mathrm{mg} / \mathrm{mL})\end{array}$ & $\begin{array}{c}\text { Total } \\
\text { protein } \\
(\mathrm{mg})\end{array}$ & $\begin{array}{c}\text { Specific activity } \\
(\mathrm{U} / \mathrm{mg} / \mathrm{Sec})\end{array}$ & $\begin{array}{c}\text { Purification } \\
\text { fold }\end{array}$ & $\begin{array}{c}\text { Yield } \\
(\%)\end{array}$ \\
\hline Crude & 500 & 0.0007 & 0.35 & 1.12 & 560 & 0.0006 & 1 & 100 \\
$\begin{array}{c}(\mathrm{NH}) \mathrm{SO}_{1} \\
\begin{array}{c}\text { Sephadex } \\
\text { G-75 }\end{array}\end{array}$ & 30 & 0.0071 & 0.213 & 0.94 & 28.2 & 0.0076 & 0.2 & 60.9 \\
\hline
\end{tabular}

Enzyme purification generally involves a series of fractionations by which an enzyme protein is separated from other proteins. Crude lipase enzyme from Klebsiella pneumoniae was therefore subjected to purification after which the enzyme showed an increase in enzyme activity from 0.0007 to $0.0071 \mathrm{U} / \mathrm{Sec}$ with a purification fold of 12.7 and $60.9 \%$ recovery following ammonium sulphate precipitation at $40 \%$ saturation (Table 3). Five millilitre of the ammonium sulphate fraction was loaded unto sephadex G-75 gel filtration column and one activity peak was observed (fraction 31) as depicted in Figure 2. The enzyme activity and protein concentration of the purified enzyme were determined to be $0.008 \mathrm{U} / \mathrm{Sec}$ and $0.04 \mathrm{mg} / \mathrm{mL}$ respectively (Table 3). The purification process resulted in 26.3-fold purification factor and a final recovery (yield) of $18.8 \%$ of the enzyme with specific activity of 0.2 $\mathrm{U} / \mathrm{mg} / \mathrm{Sec}$. Generally, it was observed that increase in the purity of the enzyme resulted to an increase in activity. This is in in accordance with expected theory which has it that, enzyme purification generally results to an increase in enzyme activity [2].
The optimum $\mathrm{pH}$ for lipase activity was observed at 8.0 from $K$. pneumoniae suggesting the lipase enzyme to be slightly alkaline in nature (Figure 3). The $\mathrm{pH}$ value obtained in this study is in tandem with the highest lipase activity at $\mathrm{pH} 8.0$ from a Bacillus strain as reported by Saraswat [23] although, a pH range of $8-9$ has been reported by Nawani [24] from some Bacillus species. Priji [25] reported the lipase from Pseudomonas aeruginosa strain with an alkaline $\mathrm{pH}$ to be suitable for detergent manufacturing. The lipase from $K$. pneumoniae may be used in detergent formulations because of its alkaline property. As seen in Figure 4, lipase from K. pneumoniae was optimally active at $30{ }^{\circ} \mathrm{C}$ suggesting it to be mesophilic. Litthauer [26] reported that bacterial lipases generally have temperature optima in the range of $30-$ $60{ }^{\circ} \mathrm{C}$. Conversely, reports also exist on lipases of bacterial origin with optima in both lower and higher ranges [27]. Saraswat [23] reported lipase activity from $B$. subtilis at a temperature range of 30 and $50{ }^{\circ} \mathrm{C}$. Salgado [28] have reported the use of mesophilic lipases in bioremediation and waste water treatment. The lipase from this study may as well be used for the same purpose. 


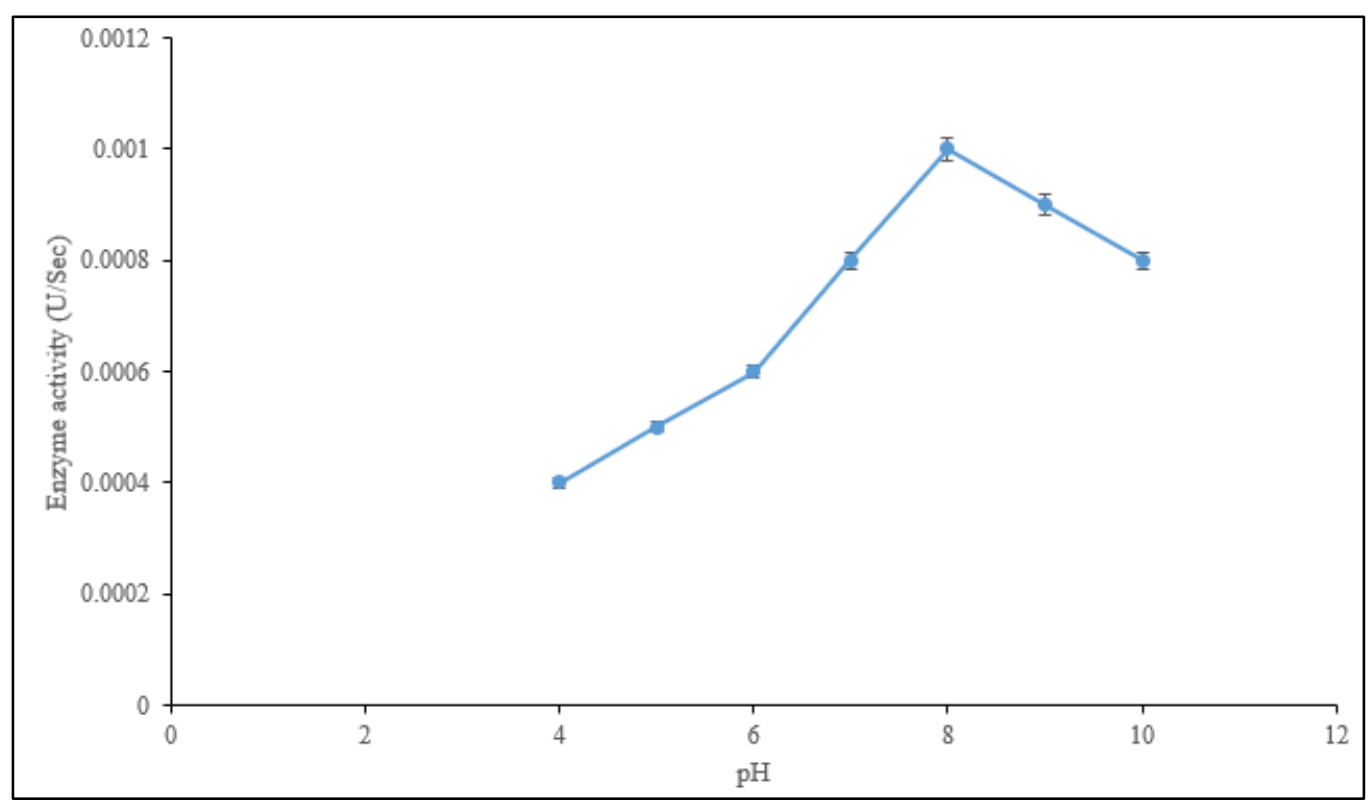

Figure 3. $\mathrm{pH}$ activity profile for purified lipase from Klebsiella pneumoniae using Tris-HCl buffer

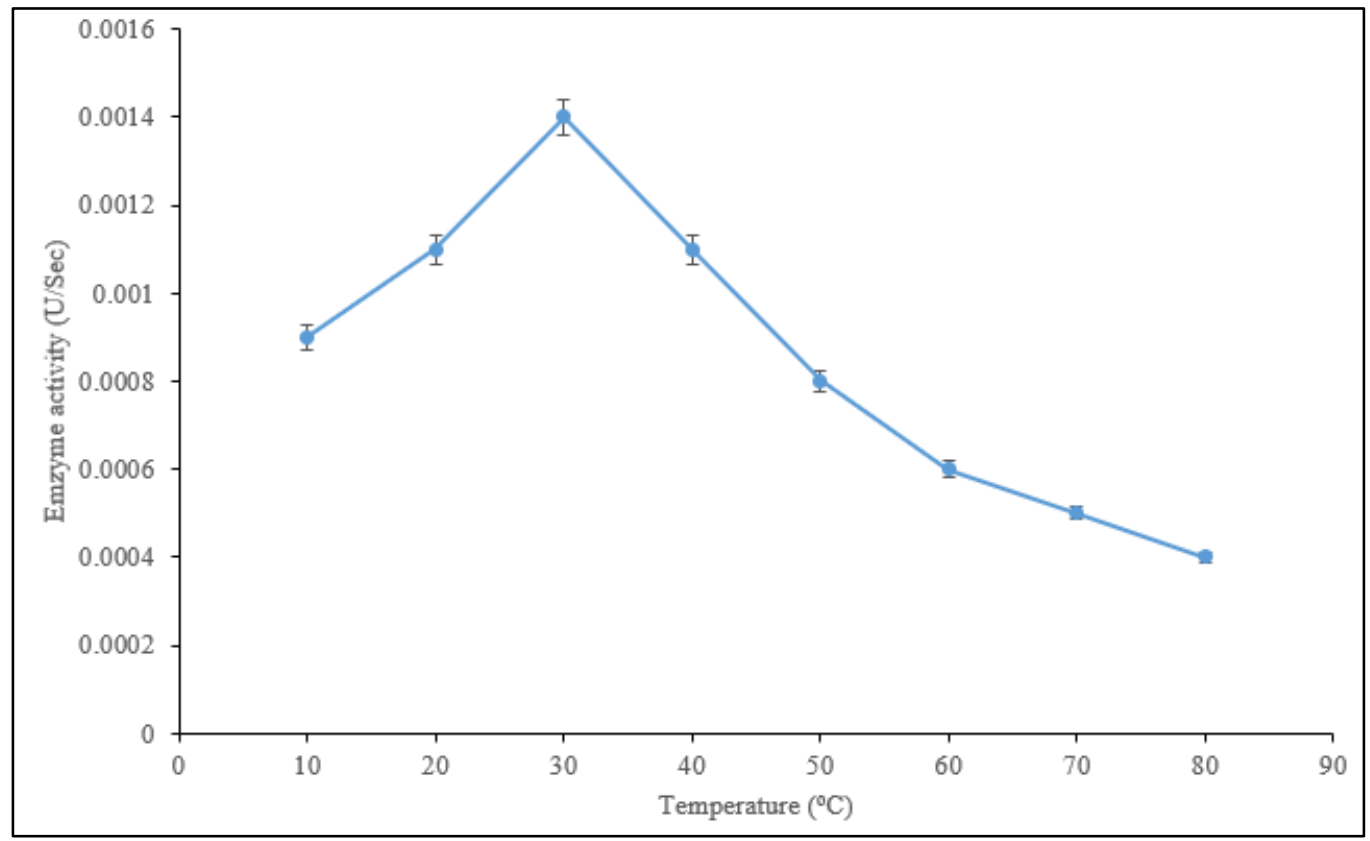

Figure 4. Optimum temperature of activity of purified lipase from Klebsiella pneumoniae isolated from a vegetable oil contaminated soil

Table 4. Effect of different substrates on the activity of purified lipases from Klebsiella pneumoniae from a vegetable oil contaminated soil

\begin{tabular}{|c|c|c|}
\hline \multicolumn{3}{|c|}{ Lipase activity $\left(\mathrm{U} / \mathrm{Sec} \times 10^{-4}\right)$} \\
\hline Palm oil & Groundnut oil & Olive oil \\
\hline $11 \pm 0.6$ & $14 \pm 1.7$ & $15 \pm 1.2$ \\
\hline
\end{tabular}

Lipase activity was determined to be highest when olive oil was used as the substrate than in groundnut oil and palm oil (Table 4). In a similar investigation by Ezema [29], the highest enzyme activity was obtained with olive oil. This suggests that, olive oil could be a potent substrate for lipases from isolates of the different oil contaminated soil. From the results obtained, olive oil may be the potent substrate among the three substrates studied.

It has been established that metal ions play a significant role in enzyme catalysis by binding to amino acid residues with negative charges at specific sites [30,31]. From this study (Figure 5), $\mathrm{MgCl}_{2}$ and $\mathrm{CaCl}_{2}$ enhanced the activity of the partially purified lipase from K. pneumoniae while $\mathrm{KCl}$ had no effect on the activity of the enzyme. $\mathrm{FeCl}_{3}, \mathrm{HgCl}_{2}$, $\mathrm{CuSO}_{4}$ and $\mathrm{CoCl}_{2}$ on the contrary showed inhibitory effects on the activity of the enzyme. Ghori [20] reported $\mathrm{Mg}^{2+}$ to enhance the activity of lipase from Bacillus sp. This is analogous to the findings of this study and that of Saun [32] from the Bacillus aerius studied. Saraswat [23] and Wang [33] reported $\mathrm{K}^{+}$to speed up lipase activity. $\mathrm{K}^{+}$on the other 
hand had no effect on the activity of lipases studied by Ghori [20]. This is in line with the findings of this study. Saraswat [23] have reported $\mathrm{Cu}^{2+}$ and $\mathrm{Co}^{2+}$ to inhibit lipase activity which corresponds to the findings of this study. Changes in the activities of lipases from different sources following the addition of various metal ions showed that different ions produced different level of conformational changes to the enzymes [34]. It may be concluded that $\mathrm{MgCl}_{2}, \mathrm{KCl}$ and $\mathrm{CaCl}_{2}$ produced a conformational change to a more active form of the enzyme studied.

The Lineweaver-Burk plot of the partially purified lipase from Klebsiella pneumoniae is depicted in Figure 6. The
$\mathrm{V}_{\max }, \mathrm{K}_{\mathrm{m}}$ and $\mathrm{K}_{\mathrm{cat}}$ were found to be $0.0006 \mathrm{U} / \mathrm{Sec}, 0.4960$ $\mathrm{mM}$ and $0.0125 \mathrm{~S}^{-1}$ respectively. In a similar vein, the energy of activation and half-life of the enzyme were determined to be $26.689 \mathrm{KJ} / \mathrm{mol}$ and $0.16 \mathrm{hr}$ correspondingly (Table 4).

Table 5. Energy of activation and half-life of purified lipase from $K$. pneumoniae of a vegetable oil contaminated soil

\begin{tabular}{|c|c|}
\hline Energy of activation $(\mathrm{KJ} / \mathrm{mol})$ & Half-life $(\mathrm{hr})$ \\
\hline $26.689 \pm 5.8 \times 10^{-4}$ & $0.16 \pm 5.8 \times 10^{-3}$ \\
\hline
\end{tabular}

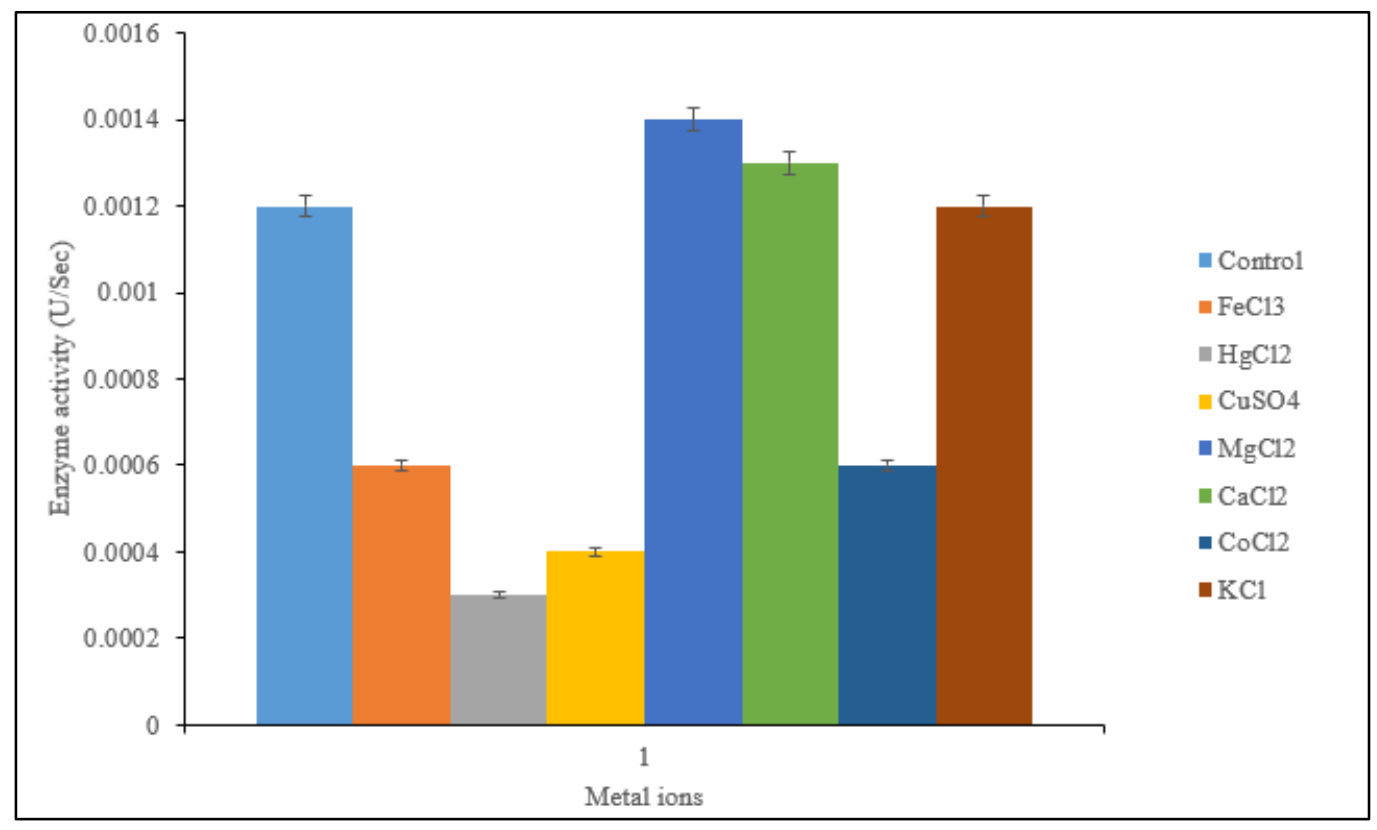

Figure 5. Effect of metal ions on the activity of purified lipase from Klebsiella pneumoniae isolated from a vegetable oil contaminated soil

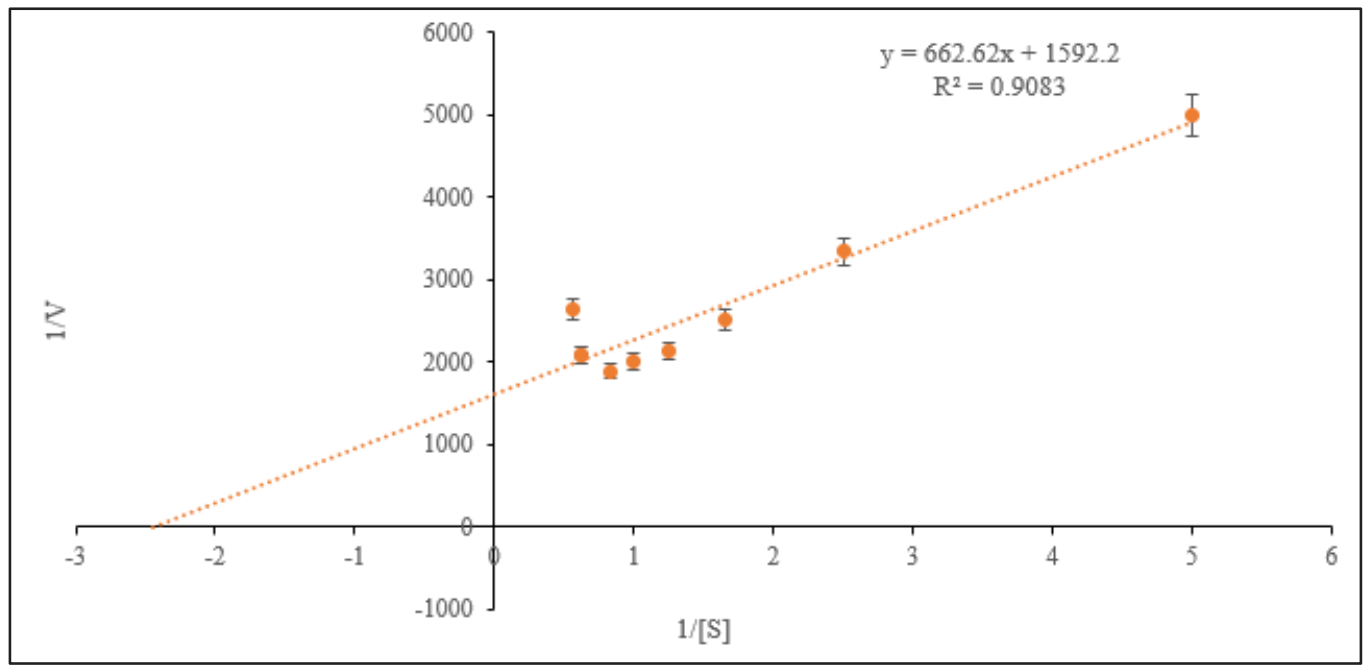

Figure 6. Lineweaver-Burk plot of purified lipase from K. pneumoniae isolated from a vegetable oil contaminated soil 


\section{Conclusions}

An extracellular lipase from $K$. pneumoniae was partially purified by ammonium sulphate precipitation and gel chromatography with a yield of $18.8 \%$ and purification fold of 26.3. The partially purified enzyme was maximally active at $30{ }^{\circ} \mathrm{C}$ and at $\mathrm{pH}$ 8.0. The enzyme had a wide affinity for different substrates with highest activity observed in olive oil substrate. $\mathrm{MgCl}_{2}$ and $\mathrm{CaCl}_{2}$ activated the enzyme to a more active form while $\mathrm{KCl}$ had no effect the activity of the enzyme. The findings of the present study suggest $K$. pneumoniae isolated from a vegetable oil contaminated soil as a novel lipase producer with the capacity to meet the numerous biotechnological applications such as bioremediation, detergent manufacturing and waste water treatment.

\section{Acknowledgements}

Authors are very grateful to TETFUND Nigeria for funding this research.

\section{REFERENCES}

[1] P. Pallavi1, T. Ravikumar, S. Ram Reddy. Isolation and characterization of lipase producing bacteria for biodegradation of oil contamination, International Journal of Current Research and Academic Review, Vol. 3, No. 8, 2015.

[2] S. Javed, F. Azeem, S. Hussain, I. Rasul, H. M. Siddique, M. Riaz, M. Afzal, A. Kouser, H. Nadeem. Bacterial Lipases: A Review on Purification and Characterization, Progress in Biophysics and Molecular Biology, 2017.

[3] M. M. Aly, S. Tork, S. M. Al-Garni, L. Nawar. Production of lipase from genetically improved Streptomyces exfoliates LP10 isolated from oil-contaminated soil. African Journal of Microbiology Research, Vol.6, No.6, 1125 - 1137, 2012.

[4] V. S. Hombalimath, U. B. Basavaraj, L. R. Patil, S. R. Anil, Y. A. Deepak, T. Gururaj. Isolation and characterization of lipolytic microorganisms from oil contaminated soil. International Journal of Advances in Engineering, Science and Technology (IJAEST), Vol.2, No.3, 293 - 297, (2012).

[5] B. Sharada, Ramakrishna Molecular characterization and partial purification of lipase from lipolytic bacteria isolated from oil mills. European Journal of Biotechnology and Bioscience, Vol.4, No.6, 13 - 19, 2016.

[6] H. Treichel, D. de Oliveira, M. A. Mazutti, M. Di Luccio, J. V. Oliveira. A review on microbial lipases production. Food Bioprocess Technology, Vol.3, 182 - 196, (2010).

[7] M. Mori, E. Ali, D. Du, Y. E. Park, E. Y. Characterization and optimization of extracellular alkaline lipase production by Alcaligenes sp. using stearic acid as carbon source. Biotechnology and Bioprocess Engineering, Vol.14, No.2, 193 - 201, 2009.
[8] M. Li, L. Yang, G. Xu, J. Wu. Cloning and characterization of a novel lipase from Stenotrophomonas maltophilia GS11: The first member of a new bacterial lipase family XVI. Journal of Biotechnology, Vol.228, 30 - 36, 2016.

[9] B. Madan, P. Mishra. Co-expression of the lipase and foldase of Pseudomonas aeruginosa to a functional lipase in Escherichia coli. Applied Microbiology and Biotechnology, Vol.85, No.3, 597 - 604, 2010.

[10] M. Veerapagu, R. K. Jeya, A. Sankaranarayanan. Screening and production of lipase producing bacteria from vegetable oil industry. International Journal of Scientific Research in Science, Engineering and Technology, Vol.2, No.6, 726 732, 2016.

[11] M. Riaz, A.A. Shah, A. Hameed, F. Hasan. Characterization of lipase produced by Bacillus sp. FH5 in immobilized and free state. Annals of Microbiology, Vol.60, No. 1, 169 - 175, 2010.

[12] R. V. Tembhurkar, B. L. Dama P. N. Attarde, S. P. Zope. Production and characterization of extracellular lipases of Staphylococcus Sp. isolated from oil contaminated soil. Trends in Biotechnology Research, Vol.1, No.1, 36 - 41, 2012.

[13] V. P. Shaini, S. Jayasree. Optimization of Staphylococcus saprophyticus lipase isolated from windrow compost. International Journal of ChemTech Research, Vol.10, No.6, 393 - 399, 2017.

[14] B. Kamaladevi, P. Prabhavathi, M. Sankareswaran, S. Anbalagan, N. Radhakrishnan, D. Prabhu. Screening and medium optimization of lipase producing bacteria from saltpan. Research Journal of Chemical and Environmental Sciences, Vol.2, No.2, 72 - 77, 2014.

[15] M. Biswas, S. Sahoo, S. Maiti, S. Roy.. Isolation of lipase producing bacteria and Determination of their lipase activity from a vegetative oil contaminated soil. International Research Journal of Basic and Applied Sciences, Vol.1, No.2, 4 - 7, (2016).

[16] M. Cheesbrough. District Laboratoey Practice in Tropical Countries (Part 2), University Press, Cambridge, 2002.

[17] H. J. Bhosale, T. A. Kadam, S. R. Sukalkar, S. D. Adekar. Lipase production from Bacillus sp using soybean oil cake as substrate. International Journal of Pharmaceutical and Biological Research (IJPBR), Vol.3, No.5, 213 - 218, 2012.

[18] F. J. Plou, M. Ferrer, O. M. Nuero, M. V. Calvo, M. Alcalde, F. Reyes, A. Ballesteros. Analysis of tween 80 as an esterase/lipase substrate for lipolytic activity assay. Biotechnology Techniques, Vol.12, No.30, 183 - 186, 1998.

[19] M. M. Bradford. A rapid and sensitive method for the quantitation of microgram quantities of protein utilizing the principle of protein-dye binding. Analytical Biochemistry, Vol.72, 248 - 254, 1976.

[20] I. M. Ghori, J. M. Iqbal, A. Hameed. Characterization of a novel lipase from Bacillus Sp. isolated from tannery wastes. Brazilian Journal of Microbiology, Vol.42, No.1, 22 - 29, 2011.

[21] S. Ramesh, R. Kumar, R. A. Devi, K. Balakrishnan. Isolation of a lipase producing bacteria for enzyme synthesis in shake flask cultivation. International Journal of Current 
and Microbiology Applied Sciences, Vol.3, No.3, 712 - 719, 2014.

[22] Zarevucka, M, Olive Oil as Inductor of Microbial Lipase, Online available from Intechopen.com.

[23] R. Saraswat, V. Verma, S. Sistla, I. Bhushan, I. Evaluation of alkali and thermotolerant lipase from an indigenous isolated Bacillus strain for detergent formulation. Electronic Journal of Biotechnology, 2017. doi:10.1016/j.ejbt.2017.08.00

[24] N. Nawani, J. Khurana, J. Kaur. A thermostable lipolytic enzyme from a thermophilic Bacillus sp.: purification and characterization. Molecular and Cellular Biochemistry, Vol.290, No.1-2, 17 - 22, 2006.

[25] P. Priji, N. K.Unni, S. Sajith, P. Binod, S. Benjamin. Pseudomonas aeruginosa strain BUP2, a novel bacterium inhabiting the rumen of Malabari goat, produces an efficient lipase. Biotechnology and Applied Biochemistry, Vol.62, No.1. 71 - 78, 2015.

[26] D. Litthauer, A. Ginster, E. Skein. Pseudomonas luteola lipase: a new member of the 320-residue Pseudomonas lipase family. Enzyme and Microbial Technology, Vol.30, No.2, 209 - 215, 2002.

[27] A. Sunna, L. Hunter, C. A. Hutton, P. L. Bergquist. Biochemical characterization of a recombinant thermoalkalophilic lipase and assessment of its substrate enantioselectivity. Enzyme and Microbial Technology, Vol.31, No.4, 472 - 476, 2002.

[28] M. J. Salgado, L. Abrunhosa, A. Venancio. M. J. Dominguez, I. Belo. Combine bioremediation and enzyme production by Aspergillus sp. in olive mill and winery waste-waters. International Biodeterioration and Biodegradation, 110, 16 -
23, 2016.

[29] O. B. Ezema. Purification and characterization of lipase (EC.3.1.1.3) from the seeds of Cucumeropsis mannii (white melon). Being a project report submitted to the School of Postgraduate Studies in partial fulfilment of the requirements for the award of Master of Science (M.Sc) Degree in Biochemistry, University of Nigeria, Nsukka. 1 86, 2012

[30] A. Colak, D. Şişik, N. Saglam, S. Güner, S. Canakçi O.A. Beldüz. Characterization of a thermoalkalophilic esterase from a novel thermophilic bacterium, Anoxybacillus gonensis G2. Bioresource Technology, Vol.96, No.5, 625 631, 2005.

[31] S. Ulker, A. Özel, A. Çolak S. A. Karaoğlu. Isolation, production, and characterization of an extracellular lipase from Trichoderma harzianum isolated from soil. Turkish Journal of Biology, Vol.35, No.5, 543 - 550, 2011.

[32] K. N. Saun, P. Mehta, R. Gupta. (2014). Purification and physicochemical properties of lipase from thermophilic Bacillus aerius. Journal of Oleo Science, Vol.63, No.12, $1261-1268$

[33] H. Wang, S. Zhong, H. Ma, J. Zhang. Screening and characterization of a novel alkaline lipase from Acinetobacter calcoaceticus 1-7 isolated from Bohai Bay in China for detergent formulation. Brazillian Journal of Microbiology, Vol.43, No.1, 148 - 56, 2012.

[34] R. Hertady, \& H. Widhyastuti. Effect of $\mathrm{Ca}^{2+}$ on the activity and stability of lipase isolated from Chromohalobacter japonicus BK-AB18. Procedia Chemistry, Vol.16, 306 - 313, 2015. 